\title{
Association of nutrition knowledge, practice, supplement use and nutrient intake with athletic performance among Taekwondo players in Nepal
}

Dev Ram Sunuwar ( $\square$ devramsunuwar@gmail.com )

Nepal Armed Police Force Hospital https://orcid.org/0000-0002-2544-8296

Devendra Raj Singh

Asian College for Advance Studies, Purbanchal University

Man Prasad Bohora

Asian College for Advance Studies, Purbanchal University

Vintuna Shrestha

Dhaulagiri Prabhidik Shikshya Pratisthan, CTEVT, Baglung, Nepal

Kshitij Karki

Asian College for Advance Studies, Purbanchal University

Pranil Man Singh Pradhan

Tribhuvan University Institute of Medicine

Research article

Keywords: Nutritional knowledge, Supplement use, Nutrient intake, Athletic performance, Taekwondo, Nepal

Posted Date: January 6th, 2021

DOI: https://doi.org/10.21203/rs.3.rs-29955/v2

License: (c) (1) This work is licensed under a Creative Commons Attribution 4.0 International License. Read Full License 


\section{Abstract}

Introduction: Adequate knowledge on nutrition and dietary intake are important to enhance the athletic performance. When athletes' nutrition requirements are not met, they are more likely to be exhausted compromising athletic performance. The main objective of this study was to measure the association of nutritional knowledge, practice, supplement use, and nutrient intake with athletic performance among Nepalese Taekwondo (TKD) players.

Methodology: We conducted an analytical cross-sectional study among 293 Taekwondo players of Kathmandu Metropolitan City, between August 2019 and January 2020. A two-stage cluster random sampling technique was used to select respondents for this study. Face-to-face interviews were carried out using semi-structured questionnaires. Nutrition knowledge (NK), nutrition practice (NP), supplement use, nutrient intake using 24-hour dietary recall, and anthropometric measurements were taken. A handgrip dynamometer was used to assess the handgrip strength (HGS) as an indirect measure of athletic performance. Univariate and bivariate analyses were used to find out the association of predictor and outcome variables. Data were analyzed using Stata/MP version 14.1.

Results: Out of 293 participants, more than half (56.3\% and 55.6\%) had poor nutrition knowledge and nutrition practice scores, respectively. Total energy $(2368 \mathrm{Kcal})$, carbohydrate $(430.5 \mathrm{gm})$, protein $(79.5$ $\mathrm{gm}$ ), fat (71.2 gm), calcium (416 mg), and iron (7 mg) intake among TKD players were significantly lower than the corresponding Recommended Dietary Allowances (RDA) for athletes. Nutritional knowledge score $(r=0.117, p<0.045)$, height $(r=0.538, p<0.001)$, weight $(r=0.651, p<0.001), B M l(r=0.347, p<0.001)$, fat $(r=0.075, p<0.002)$, and energy $(r=0.127, p<0.029)$ intake showed significant positive correlation with handgrip strength of athletes. The athletic performance were positively associated with training hours per day ( $\beta=0.41,95 \%$ Cl: $0.09-0.91)$, BMI ( $\beta=0.35,95 \%$ Cl: $0.09-0.61)$, NK score $(\beta=0.13,95 \%$ Cl: 0.01-0.25), and energy intake $(\beta=0.13,95 \% \mathrm{Cl}: 0.12=0.14)$.

Conclusions: The results suggest that nutritional knowledge and nutrient intake both were poor among TKD athletes. Height, weight, BMI, nutritional knowledge, energy, and fat intake showed positive correlation with athletic performance. Future studies can build on the premise of this study to identify the robust relationship between nutritional knowledge, practice, different supplement use, and nutrient intake among athletes.

\section{Background}

Taekwondo, also known as Tae Kwon Do (TKD), is one of the oldest form of martial art and combat sport, originated from Korea since last 2000 years [1]. In the 2000 Olympic Games, TKD made its debut as a fully recognized official Olympic medal sport [2]. The World Taekwondo Federation (WTF) defined TKD as "the right way of using all parts of the body to stop fights and help to build a better and more peaceful world" [1]. Over the recent years, TKD has gained substantial attention from participants, national governments, and scientists alike, and is evolving as a martial art sport in the world [3,4]. According to 
2020 figures of WTF, TKD is practiced by an estimated 80 million people in 210 countries, making it one of the world's most popular sports [1]. TKD was introduced in Nepal as a martial arts discipline in 1983. According to the Nepal Taekwondo Association, a total of 85 schools are formally registered across the country so far [5]. TKD is predominantly an anaerobic sport (both alactacide and lactacide) with a significant aerobic component too [6].

As TKD is a weight class sport, the nutritional status of the athletes is an important aspect of performance [4]. Adequate nutrition has not only a leading role to meet the player's optimum sports performance but also has a crucial role in improving their physical, technical, and tactical training [6,7]. The joint position statement authored by the Academy of Nutrition and Dietetics (AND), and the Dietitians of Canada (DC) and the American College of Sports Medicine (ACSM), stresses the critical role of optimal nutrition in athletic performance and recovery from exercise [8]. Adequate nutritional knowledge and nutrition are considered as the key components that play a pivotal role in enhancing athletic performance $[9,10]$. Inadequate nutrition knowledge can have a serious impact on the nutritional status and performance of athletes [11]. Incomplete and inadequate information provided by family, teammates, and coaches can also contribute negatively to the athlete's performance [12]. In addition, insufficient diet intake and excessive energy expenditure could lead to relative energy deficiency in sport (RED-S) among athletes [13]. The RED-S could be exacerbated by poor nutrition knowledge and attitudes towards eating behavior ultimately diminishing the athletic performance [14]. Previous studies have shown that the athletes who have adequate nutrition knowledge are more likely to meet optimum nutrition requirements [15-17]. The adequate nutritional knowledge of TKD athletes is crucial for their ability to cope with the stressful situations they may experience physically, physiologically, and mentally, particularly during training and competitions [18]. The TKD players should consider nutritional requirements, adequate calorie intake, adequate fluid intake and meal timing to achieve the desired success and performance $[8,18]$.

Previous studies have shown that nutrition can affect health, body weight and composition, substrate availability during exercise, recovery after exercise, essential elements for optimal sports performance [8]. Good nutrition predicts the ability to train intensely, muscle recovery and metabolic adaptations to athletes [6]. A balance of diet is critical that entails good nutrition management, including the regulated intake of carbohydrates, fats, protein, vitamins, minerals, and water [19]. A good athlete diet must meet not only the biological needs of calorie, but also the psychological and social aspects [8]. The ideal diet for combat sports such as TKD should bring a total caloric intake of $60-65 \mathrm{kcal} / \mathrm{kg}$ body weight with high proportion of carbohydrates and a low proportion of lipids with adequate supply of protein and plenty of fluid [6]. Optimal dietary carbohydrate needs to maintain blood glucose levels during exercise and replace muscle glycogen [8]. High-quality protein is needed to support muscle protein synthesis, reduce muscle protein breakdown and repair muscle damage [20]. In addition, the optimal timing of protein intake should also be considered when determining and prescribing protein requirements, as this can lead to faster recovery times and improved adaptation after training [19]. An adequate amount of fat is necessary to consume to ensure optimal health; maintenance of energy balance; optimal intake of fatty acids, and fat-soluble vitamins; and to replenish intramuscular triacylglycerol stores [19,21]. According to 
the joint position statement authored by the AND, DC and ACSM, carbohydrate and protein recommendations for endurance and strength-trained athletes range from 6-10 g/kg body weight, and $1.2-1.7 \mathrm{~g} / \mathrm{kg}$ body weight respectively as well as fat intake should range from $20-30 \%$ of total energy intake [8]. Fluid intake is recommended at a rate of $0.5-2 \mathrm{l} /$ hour, which needs to maintain fluid balance and prevent dehydration. Specifically, fluid intake should be frequent (every 5-20 minutes) with smaller amounts (150-200 ml) per episode [19]. Optimal micronutrients are essential for athletes in line with their metabolic demands. Increase in hemoglobin productions, blood volume, and muscle mass are normal characteristics of growth and maturation, and account for the majority of amplified iron needs [21,22]. The ACSM recommended that no additional vitamin and mineral supplementation is needed if an athlete obtains sufficient energy from wide variety of foods [8]. Supplementation may be individually prescribed for certain athletes, who have special dietary restrictions or requirements such as vegetarians, and those recovering from injury or those suffering with special medical condition [8].

There is a paucity of evidence-based studies exploring factors affecting nutritional knowledge, practice, different supplement use, and nutrient intake with athletic performance among TKD players in Nepal. The main objective of this study was to generate evidence on nutritional knowledge, practice, the prevalence of supplement use, nutrient intake, and associated athletic performance among TKD players.

\section{Methods}

Study design and setting

This was a cross-sectional study conducted among TKD players of Kathmandu Metropolitan City, Nepal between August 2019 and January 2020. Kathmandu is also a capital city of Nepal and hosts $20 \%$ of the country's urban population [23]. The city is the center for the majority of sports schools, and 50 out of 85 Taekwondo schools of the country are located within this area [5]. The athletes who were actively involved in the Taekwondo game and aged 15-36 years were included in the study. Taekwondo players who were absent on the day of the data collection and those who had a special medical condition such as illnesses were excluded from the study.

Sample size, sampling strategy

A total sample size of 293 was estimated based on the single proportional formula $n=Z^{2} p q / d^{2}$; taking $50 \%$ proportion rate with a level of significance at $5 \%$. In the formula, $Z=$ standard normal deviation and equaled 1.96 at a level of significance; $p$ is the prevalence of the outcome of interest which was set at 0.5 considering the unknown prevalence of nutritional knowledge or nutritional practice among TKD players in the study area; $q=1-p$; and the margin error (d) was set at $6 \%$ and $10 \%$ non-response rate was added.

A two-stage cluster random sampling technique was used to select the desired number of respondents for the study. In the first stage, we considered each of the 35 wards within Kathmandu Metropolitan City as an individual cluster, and then we randomly selected 12 clusters out of 35 clusters. In the second stage, we randomly selected two Taekwondo schools through the lottery method from the lists of the 
clubs from each cluster. Finally, we selected 24 Taekwondo schools for the study and interviewed all players who met the study criteria. The list of schools was obtained from the Nepal Taekwondo Association (NTA) website [5].

\section{Data collection and study variables}

Data were collected by trained undergraduate public health students who were provided with a three-days training that included the objective of the study, data collection procedure, sampling method, ethical aspects of the study, and data entry techniques. Face-to-face interviews were conducted using pre-tested semi-structured questionnaires. Interviews were conducted at the Taekwondo School's premises or the training grounds at least 45 minutes before or after the training. The questionnaire consisted of three parts: (1) socio-demographic information (age, sex, education, religion, ethnicity, occupation, monthly income, family type, and smoking habit and alcohol consumption habit) and anthropometric characteristics (height, weight, and $\mathrm{BMI}$ ), (2) nutritional knowledge, nutritional practice, nutrient intake, and supplement use and (3) exercise-related characteristics: training hour per day, handgrip strength as an athletic performance using a handgrip dynamometer. All the tools were originally developed in English language. Further, the tools were translated into Nepali language and were back-translated into English to ensure the validity (and reliability) of the tool. Pretesting of the tools was carried among 30 Taekwondo players from the clubs located in the areas of Lalitpur Metropolitan City. The research committee, faculty members, and dietitian reviewed the pre-tested questionnaire to establish the validity and reliability of questionnaire. The questionnaire was revised appropriately based on their feedback. The Nepalese version of nutrition knowledge and practice questionnaire had acceptable internal consistency, Cronbach's alpha of 0.70 , and 0.69 , respectively.

\section{Outcome variable}

Handgrip strength (HGS), as an indirect measure of athlete performance, was assessed with the handgrip dynamometer. Measurements were performed for both hands, and handedness (dominance and nondominance) was determined based on self-report and the dominant handgrip strength (DHGS) [17,24]. Handgrip strength was measured using a standard adjustable digital handgrip dynamometer (Hand Grip Dynameters Labappara, Ambala Cantt, Haryana of India) at the standing position with shoulder adducted, and neutrally rotated, and elbow in full flexion. The dynamometer was held freely without support. The participants were asked to squeeze the handle maximally and to sustain it for 3-5 seconds. All measurements were performed for both hands, and measurements were performed thrice, and the mean value was documented. One-minute rest was provided between each attempt, and hands were alternated to minimize fatigue effects. The results were documented in kilogram-force (kgf). The handgrip dynamometer was calibrated before each assessment.

\section{Predictor variables}

Information on participants' age, sex, ethnicity, religion, education, monthly income, sources of information, consumption of alcohol and tobacco, nutrition knowledge, practice, nutrient intake, and 
supplement use were collected.

Questionnaires on nutritional knowledge and practice, and procedure used for the classification were adapted from previous works $[17,25,26]$. The mean nutrition knowledge (NK) score was calculated based on the responses of the participants. The participants scored 1 for every correct answer and zero for every wrong answer and 'not sure option'. The scores were added, and the mean \pm SD nutrition knowledge score $(9.0 \pm 2.0)$ was calculated. Those participants who scored less than the mean nutritional knowledge score were classified as having poor knowledge while those participants who scored equals to/or more than the mean nutrition knowledge score were classified as having good NK. The mean \pm SD nutrition practice score $(10.2 \pm 1.8)$ was calculated based on the responses of the participants. The scoring process for NP and categorizing poor NP and good NP were similar to the procedure used for the classification of nutrition knowledge.

Pre-tested 24-hour dietary recall tool, based on Nepalese food and beverage was used to assess the previous 24 hours (midnight to midnight) nutrient intake of the participants. During 24-hour recall, the athletes were asked to name all the food and drink items consumed during the preceding day, including anything consumed outside the home and the time of consumption was also recorded. If multiple servings of the same food items were reported to be consumed in a single eating occasion then these amounts were combined to a single portion. The portion size of items consumed was estimated using graduated measuring cylinder and standard weight for foods that are served as a unit (boiled egg, bread slice), as per the principle and guideline of the Indian Institute for Medical Research (ICMR) [27]. Based on the information obtained from the 24 hour dietary recall method, the amount of foods was then converted into daily nutrient intakes. The mean daily intake of total calorie, carbohydrate, protein, fats, calcium, and iron over 24 hour recalls was calculated accordingly using the Nutrition Society of India (NSI) diet calculator developed by the National Institute of Nutrition, ICMR, Hyderabad, India [28].

The anthropometric measurements including weight and height of the participants were measured according to standardized procedures. Weight was measured to the nearest $0.1 \mathrm{~kg}$ using a digital weighing machine three times; and the average values were documented. Height was measured in the standing position to the nearest $0.1 \mathrm{~cm}$ with a portable stadiometer three times with one-minute rest in between and the mean value was documented. The body mass index (BMI) was calculated using weight $(\mathrm{kg})$ divided by height squared $\left(\mathrm{m}^{2}\right)$ and categorized using the World Health Organization (WHO) cut-off points for BMI [29].

\section{Data management and analysis}

Data checking, compiling, and editing was done manually to ensure completeness and accuracy before data were entered for analysis. Pre and post coding was done. The collected data were entered into EpiData software 3.1v and transferred into Stata version 14.1 (StataCorp LP, College Station, Texas) for statistical analysis. The normality of the distribution of continuous variables was evaluated using the Kolmogorov-Smirnov test, and skewness-kurtosis test. The descriptive results were presented in the form 
of mean, standard deviation, frequency, and percentage for normally distributed data and non-normally distributed data were expressed as median and interquartile range. Pearson's chi-square $(\chi 2)$ was applied for categorical variables, and independent sample t-test and one-way analysis of variance (ANOVA) tests were performed to observe differences in socio-demographic characteristics and athletic performance. Wilcoxon signed-rank test was used to assess the macro and micronutrient intake compared to the corresponding RDA of TKD players. Pearson correlation and simple linear regression analysis were used to observe the relationship between the predictor and outcome variables. The statistical significance was considered at $p$-value $<0.05$ and $95 \%$ confidence intervals (Cls).

\section{Ethical considerations}

The ethical approval for this study was obtained from the ethical review board of the Nepal Health Research Council (Ref.no 53/2019). Formal permission was also obtained from the respective Taekwondo schools. Written informed consents were obtained from all parents or legal guardians for eligible participants who were aged $\leq 18$ years, and participants themselves for aged $>18$ years before proceeding to data collection. The data collectors shared the objectives of the study among each athlete, and coaches of respective schools before the data collection. Participants were informed about voluntary participation, their right to refusal at any point, and the confidentiality of their identity.

\section{Results}

\section{Characteristics of the participants}

Out of 293 participants, $63.1 \%$ were male and rest were female. More than half of the participants (55.4\%) had completed a higher secondary or higher level of education (University level of education) while $45 \%$ had completed secondary or lower level of education. About three-fourths of the participants $(73 \%)$ were engaged in less than 4 hours of training per day while the one-fourth of them were engaged in $\geq 4$ hours of training per day. The majority of the participants did not smoke $(97.6 \%)$ and consumed alcohol (97.6\%). The mean ( \pm SD) scores of NK and NP were $9( \pm 2)$ and $10.2( \pm 1.8)$ respectively. More than half of the participants $(56.3 \%$ and $55.6 \%$ ) had poor NK and NP score, respectively. The mean ( \pm SD) age of the participants was $18.8( \pm 4.5)$ years (Table 1$)$. The majority of the participants $(92 \%)$ did not use any supplements. The most consumed nutritional supplements were protein powder (Fig 1). Similarly, the majority of the athletes who had a poor nutritional knowledge score also had a poor nutrition practice score $(p<0.001)$ (Table 2).

Table 1. Socio-demographic and anthropometric characteristics with DHGS score of the participants $(n=293)$

Fig 1. Type of supplements used by Taekwondo players $(n=21)$

Table 2. Nutritional knowledge and nutrition practice among Taekwondo players 


\section{Nutrient intakes among players}

The results presented in Table 2 show participants were found to be consuming nutrients below their recommended daily dietary requirements. The median (IQR) energy intake was $2367.8(2035$, $2716.8) \mathrm{kcal} /$ day, which is equivalent to $77 \%$ of the RDA for athletes. The median (IQR) intake of carbohydrate, protein, and fat was $430.5(340.9,503.8) \mathrm{gm}, 79.5(66.8,95.1) \mathrm{gm}$, and $71.2(55.5,89.2) \mathrm{gm}$, respectively. The carbohydrate intake was equivalent to $87.1 \%$ of RDA's recommended value for athletes within this population. The result shows that the demand for carbohydrates was not met as per RDA value. The protein intake was equivalent to $58.8 \%$ of RDA's recommended value for athletes within this population. The fat intake was equivalent to $57.4 \%$ of RDA's recommended value for athletes within this population. The median (IQR) calcium and iron intake were $416(178,448) \mathrm{mg}$ and $7(3.8,12) \mathrm{mg}$, respectively. The calcium intake was equivalent to $47 \%$ of RDA's recommended value for athletes within this population. The iron intake was low and equivalent to $32 \%$ of RDA's recommended value for athletes within this population.

Table 3 Description of daily nutrient intake per day compared to corresponding RDA of Taekwondo player $(n=293)$

\section{Correlation of athletic performance with different covariates}

Table 4 presents the correlation of anthropometric measurements, nutrition knowledge, practice, supplement use, and nutrient intake with athletic performance among Taekwondo players. Various factors were found to have a positive correlation with athletic performance. Nutritional knowledge score $(r=0.117, p<0.045)$, height $(r=0.538, p<0.001)$, weight $(r=0.651, p<0.001)$, BMI $(r=0.347, p<0.001)$, fat $(r=0.075, p<0.002)$, and energy $(r=0.127, p<0.029)$ intake were positively correlated with handgrip strength of athletes.

Table 4 Correlation of anthropometric measurements, nutrition knowledge, practice and nutrient intake with athletic performance among Taekwondo players $(n=293)$

Table 5 linear regression analysis of anthropometric measurement, nutrition knowledge, practice and nutrient intake with athletic performance among Taekwondo players $(n=293)$

Table 5 presents the linear regression analysis of anthropometric measurements, nutrition knowledge, practice, and nutrient intake with athletic performance among Taekwondo players. The DHGS was positively associated with training hour per day $(\beta=0.41,95 \% \mathrm{Cl}:-0.09-0.91, P<0.001), \mathrm{BMI}(\beta=0.35,95 \% \mathrm{Cl}$ : 0.09-0.61, $P<0.001)$, NK score $(\beta=0.13,95 \% \mathrm{Cl}: 0.01-0.25, p=0.024)$, and energy intake $(\beta=0.13,95 \% \mathrm{Cl}$ : $0.12-0.14, p<0.035)$. About $23.7 \%$ of the variance in the DHGS, which is the measure of athletic performance is explained by this model.

\section{Discussion}


This is the first study of its kind to assess the association of nutrition knowledge, practice, and nutrient intake and supplementation use with athletic performance among Taekwondo players in Nepal. Good nutritional knowledge, practice, and adequate nutrient intake are considered a crucial components contributing to athletic performance [30].

In this study, based on the correct response of the nutrition knowledge and practice score, the study participants demonstrated a relatively low level of nutrition knowledge and practice compared to previous findings where less than half had poor nutritional knowledge [17,31]. However, our result is in line with the other studies report where overall nutrition knowledge scores were low [10,32]. Optimum nutrition knowledge is an essential factor for promoting athletic success to the sportsperson $[9,10]$. Inadequate nutrition knowledge can have a serious impact on the nutritional status and performance of athletes [11]. The study conducted by Walsh et al (2011) showed that poor nutritional knowledge and attitudes (dietary behaviour) had contribution to poor dietary behaviors [14]. This study revealed that those athletes who had poor nutrition knowledge were found to have poor nutrition practice scores. These findings were in line with previous findings where the correlation between nutrition knowledge and practice score of athletes were found statistically significant $[17,33]$. Lack of knowledge about nutrition in sport is considered as one of the potential barriers to optimal nutrition practices among athletes [16].

The prevalence of supplement use in the current study was found to be lower than that reported in other studies $[9,18]$. Overall, $7.2 \%$ of Taekwondo players in our study used some form of supplements. Likewise, Muwonge et al (2017) also reported the supplement-use prevalence to be $13.4 \%$ [34], which is also low compared to previous study findings $[9,18,35]$. The professional TKD players may readily use nutritional supplements mainly to maintain their health and improve athletic performance. The possible explanation for these findings could be that the assessment tools for supplements use adopted by the current study may have underestimated the true prevalence.

In this study, a total energy intake, carbohydrate, protein, fat, calcium, and iron were significantly lower than the corresponding RDA. Every athlete including TKD players needs adequate calorie from the diet in terms of optimum quality and quantity before, during, and after exercise for improved athletic performance [6]. Adequate nutrient intake and good nutrition knowledge have been recognized as key factors in improving the athletic performance, particularly in improving quality of training and recovery from injury. The median carbohydrate intake of the participants was $430.5 \mathrm{gm}$ in this study. This is equivalent to $87.1 \%$ of RDA's recommended value for athletes within this population. This result is consistent with results from Wierniuk et al (2013) and Ali A et al (2015) [11,36]. Carbohydrate is essential not only as a source of energy but it also protects the protein from being exploited as an energy source $[37,38]$. Inadequate intake of carbohydrates increases the risk of injury and exaggerates deterioration of athletic performance [32,38]. Thus, carbohydrate intake before, during, and after exercise should be scaled up according to the characteristics of the event. Even small amounts of carbohydrate solution like mouth-rinsing without swallowing, increases athletic performance through the pathway that involves central nervous system in its absorption [37]. 
The median protein intake of the participants was $79.5 \mathrm{gm}$. The protein intake was found to be inadequate in this study (only met $58.8 \%$ of corresponding RDA for athletes within this population). Inadequate protein consumption can have serious health problems in athletes such as inability to maintain proper body function and decline in sports performance [21]. A previous study showed that a protein intake of $1.4-2.0 \mathrm{~g} / \mathrm{kg}$ body weight could improve body adaptability for intensive physical activities [39]. Adequate protein intake is critical in the overall exercise training program, required for a proper and speedy recovery from injury including to bolster immune function, growth and maintenance of lean body mass [39].

The median fat intake was found to be low $(71.2 \mathrm{gm})$ in this study, which is only equivalent to $57.4 \%$ of RDA recommended value for athletes within this population. This finding is inconsistent with other findings, where the fat intake was found to have higher than RDA [32,36]. Fat is an essential component of a balanced diet, providing energy, optimum elements of cell membranes, and facilitation of the absorption of fat-soluble vitamins [40].

The median energy intake in these participants was $2367.8 \mathrm{kcal} /$ day, which is lower than the corresponding RDA, and is slightly lower than reported in the previous study in Indian Taekwondo athletes (the mean energy intake was $3129 \pm 518.9$ ) [4]. Nutrition and Hydration Guidelines states has categorized weight division game such as TKD under Group-IV sport event which demands a minimum $3600 \mathrm{Kcal}$ of daily calorie, that means $65 \%, 15 \%$, and $20 \%$ should be yield from carbohydrate, protein, and fat respectively [41].

The median intake of micronutrients: calcium $(416 \mathrm{mg})$ and iron $(7 \mathrm{mg})$ were below the RDA, which can meet only $47 \%$ and $32 \%$ of RDA value for athletes within this population. These findings are in line with the results from the other studies [4,32], where their results were also below the RDA. Adequate intake of iron, which is necessary to carry oxygen, and maintain energy production, is critical for female athletes during the high-intensity exercise, owing to their iron loss during regular menstrual cycle [42]. In addition, a sufficient amount of calcium-rich diet contributes to bolster bone mineral density and prevent injury risk [32].

Anthropometric characteristics such as height, weight, and BMI were positively correlated with athletic performance. These results are consistent with the previous studies where they reported that handgrip strength had a strong correlation with various anthropometric characteristics [17,24]. In this study, results indicated a significant relationship between NK score and athletic performance. Various previous studies reported that nutrition knowledge was positively correlated with athletic performance $[14,17,33]$. Higher nutrition knowledge of the athletes, better their attitude and practice towards a sport-enhancing diet, resulting better performance [33]. Likewise, total energy and fat intake were significantly positively correlated with handgrip strength of athletes. The previous study also reported that energy intake was positively associated with handgrip strength [17]. The most important component to optimize athletic performance through diet is to ensure the athlete is consuming enough calories to maintain positive energy balance $[7,19]$. However, it might be challenging to meet the energy needs of athletes with a high 
volume of intense training. Insufficient energy intake can result in weight loss, especially lean muscle mass, injury, illness, increased prevalence of overtraining syndrome, and ultimately decreased exercise performance [43]. Moreover, in linear regression analysis, the DHGS were positively associated with training hours per day, BMI, NK score, and energy intake. These results are consistent with Folasire OF et al (2015) findings. For better athletic performance by athletes, an adequate energy balance is needed, where energy balance occurs only when energy intake such as foods, fluids, and supplement products are equivalent to energy expenditure [21]. Energy expenditure for various exercise is dependent on the duration, frequency, intensity of the exercise, sex, age, body size of the athletes. The more energy used in the exercise, the greater calories required to achieve energy balance [40].

Our study had a few limitations. The sample size used in this study was confined to Taekwondo players, thus we cannot generalize the findings to all types of sports. There are slight differences in nutritional requirements depending on the type of sports. We used a 24-hour dietary recall method which can underestimate true nutrient intake. Also, single 24-hr recall cannot identify within and between-person variations. Although other minerals and vitamins play a key role in human health and nutritional status, we included only calcium and iron as micronutrient intake. Since the information was collected through face-to-face semi-structured questionnaires, there may have been social desirability bias. Due to the limited resources, we could not measure the body composition using a portable body composition device and also could not assess the other anthropometric measurements such as waist, neck, hip circumference. Despite the mentioned limitations, our study has some strengths. Our study included an analysis of the correlation between nutritional knowledge, practice, and nutrient intake with athletic performance. This data provide insight into the potential factors influencing athletics performance which helps in forming the basis of targeted nutrition education programs. The majority of the national Taekwondo clubs were located in Kathmandu Metropolitan City, however, the study sample included players from all levels from Nepal. The results of this study can be a reference to reform the nutritional policy for all types of athletes. This study has also set the premise to build further evidence to explore the determining factors for the nutritional knowledge and practices among Nepalese athletes.

\section{Conclusions}

This study shows that there is a gap between knowledge of nutrition and nutritional practice among Taekwondo players. Total energy intake, protein, fat, calcium, and iron intake were low against the current recommendations for athletes. BMI, nutritional knowledge, energy, and fat intake were positively associated with athletic performance. Inadequate consumption of the right diet before, during, and after competition due to lack of nutrition knowledge and dietary intakes may interfere with athletic performance. Future research is essential to explore the relationship between nutritional knowledge, practice, nutrient intake, and dietary supplement use for athletic performance among athletes of different sports. Integrating nutrition expert and their recommendations in the sports is essential to ensure athletes are on optimal diet so that it can ultimately enhance the athletic performance. 


\section{Abbreviations}

AND: Academy of Nutrition and Dietetics; ACSM: American College of Sports Medicine; BMI: Body mass index; Cl: Confidence interval; DC: Dietitian of Canada; DHGS: Dominant handgrip strength; ICMR: Indian Institute for Medical Research; HGS: Handgrip strength; NK: Nutritional knowledge; NP: Nutrition practice; NTA: Nepal Taekwondo Association RDA: Recommended dietary allowances; TKD: Taekwondo; WHO: World Health Organization WTF: World Taekwondo Federation

\section{Declarations}

Ethical approval and consent to participants

The ethical approval was obtained from the Nepal Health Research Council (Ref.no 53/2019). Formal permission was also obtained from the respective Taekwondo schools. Informed verbal consents were obtained from all parents or legal guardians for eligible participants who were aged $\leq 18$ years, and respondents themselves for aged $>18$ years before proceeding to data collection. The data collectors shared the objectives of the study among each athlete, coaches of respective clubs before the data collection. Participants were informed about voluntary participation, their right to refusal at any point, and the confidentiality of their identity.

\section{Consent for publication}

Not applicable

\section{Availability of supporting data}

Dataset used in this study is available upon reasonable request to the corresponding author.

\section{Competing interest}

The authors have declared that no competing interest exists.

\section{Funding}

This research received no specific financial support from any funding agencies.

\section{Author's contributions}


DRSu. Roles: Research design, conceptualization idea, methodology, formal data analysis, interpretation, software, validation, writing an original draft, writing review, editing and overall supervision of the research. DRSi. Roles: Research design, conceptualization idea, methodology, Data analysis, interpretation, writing an original draft, writing review, editing and overall supervision of the research. MPB. Roles: Research design, data collection, data curation, writing an original draft, writing review, editing. VS. Roles: Writing an original draft, reviewing and editing, overall supervision of the research. KK. Roles: Writing an original draft, reviewing and editing, overall supervision of the research. PMSP: Writing an original draft, reviewing and editing, overall supervision of the research. All authors read and approved the final manuscript.

\section{Acknowledgments}

We would like to thank all the participants who provided their valuable time, response, and participation in the study. We are grateful to all the coaches and members of the Taekwondo schools for facilitation, and cooperation in undertaking this research. We would also like to thank Dr. Bipin Adhikari from Nuffield Department of Medicine, University of Oxford, Oxford, United Kingdom for his kind suggestions and proofreading the final version of the manuscript.

\section{Author's information}

${ }^{1}$ Department of Nutrition and Dietetics, Armed Police Force Hospital, Kathmandu, Nepal

${ }^{2}$ Department of Public Health, Asian College for Advance Studies, Purbanchal University, Lalitpur, Nepal

${ }^{3}$ Southeast Asia Development Actions Network, Lalitpur, Nepal

${ }^{4}$ Dhaulagiri Prabidhik Shikshya Pratisthan, CTEVT, Baglung, Nepal

${ }^{5}$ Group for Technical Assistance, Lalitpur, Nepal

${ }^{6}$ Department of Community Medicine, Maharajgunj Medical Campus, Institute of Medicine, Tribhuvan University, Kathmandu, Nepal

${ }^{7}$ Nepalese Society of Community Medicine, Kathmandu, Nepal

\section{References}

1. World Taekwondo Federation (WTF). World Taekwondo [Internet]. 2020. Available from: http://www.worldtaekwondo.org/about-wt/taekwondo/ 
2. Fleming S, Costarelli V. Nutrient intake and body composition in relation to making weight in young male Taekwondo players. Nutr Food Sci [Internet]. 2007 [cited 2020 Dec 16];37:358-66. Available from: https://www.emerald.com/insight/content/doi/10.1108/00346650710828389/full/html

3. Kazemi M, Pieter W. Injuries at a Canadian National Taekwondo Championships: A prospective study. BMC Musculoskelet Disord [Internet]. 2004;5:1-8. Available from: https://bmcmusculoskeletdisord.biomedcentral.com/track/pdf/10.1186/1471-2474-5-22

4. Sarkar S, Debnath M, Chatterjee S, Karmakar N, Dey SK. Assessment of Nutritional Status, Body Composition Parameters, \& Physiological Profi les of Young Male Taekwondo and Wushu Players. Int J Sport Sci Med [Internet]. 2018;2:1-7. Available from: www.scireslit.com

5. Nepal Taekwondo Association. Nepal Taekwondo Association, International Sports Complex Satdobato, Lalitpur, Nepal. [Internet]. 2020. Available from: http://www.taekwondonepal.org.np/

6. Caramoci A, Paunescu C, Haddad M, Ionescu AM. Performance Optimization in Taekwondo: From Laboratory to Field. Nutr Diet Recomm Taekwondo [Internet]. OMICS Group eBooks 731; 2014. Available from: www.esciencecentral.org/ebooks Additional

7. Leutholtz B, Kreider RB. Optimizing Nutrition for Exercise and Sport. Nutr Heal [Internet]. Humana Press; 2001 [cited 2020 May 3]. p. 207-35. Available from: https://link.springer.com/chapter/10.1007/978-1-59259-226-5_14

8. Thomas DT, Erdman KA, Burke LM. Position of the Academy of Nutrition and Dietetics, Dietitians of Canada, and the American College of Sports Medicine: Nutrition and Athletic Performance. J Acad Nutr Diet. 2016;116:501-28.

9. Tawfik S, El Koofy N, Moawad EMI. Patterns of nutrition and dietary supplements use in young Egyptian athletes: A community-based cross-sectional survey. PLoS One. 2016;11:1-12.

10. Nazni P, Vimala S. Nutrition knowledge, attitude and practice of college sportsmen. Asian J Sports Med. 2010;1:93-100.

11. Ali A, Al-Siyabi MS, Waly MI, Kilani HA. Assessment of nutritional knowledge, dietary habits and nutrient intake of university student athletes. Pakistan J Nutr. 2015;14:293-9.

12. Shifflett $B, T i m m ~ C$, Kahanov L. Understanding of athletes' nutritional needs among athletes, coaches, and athletic trainers. Res Q Exerc Sport. Taylor \& Francis Group ; 2002;73:357-62.

13. Statuta SM, Asif IM, Drezner JA. Relative energy deficiency in sport (RED-S). Br J Sports Med. 2017;51:1570-1.

14. Walsh M, Cartwright L, Corish C, Sugrue S, Wood-Martin R. The body composition, nutritional knowledge, attitudes, behaviors, and future education needs of senior schoolboy rugby players in Ireland. Int J Sport Nutr Exerc Metab [Internet]. Human Kinetics Publishers Inc.; 2011 [cited 2020 May 2];21:365-76. Available from: https://www.ncbi.nlm.nih.gov/pubmed/21799215

15. Alaunyte I, Perry JL, Aubrey T. Nutritional knowledge and eating habits of professional rugby league players: Does knowledge translate into practice? J Int Soc Sports Nutr [Internet]. BioMed Central Ltd.; 2015 [cited 2020 Dec 21];12:18. Available from: http://www.jissn.com/content/12/1/18 
16. Werner EN, Guadagni AJ, Pivarnik JM. Assessment of nutrition knowledge in division I college athletes. J Am Coll Heal [Internet]. Taylor \& Francis; 2020;0:1-8. Available from: https://doi.org/10.1080/07448481.2020.1740234

17. Folasire OF, Akomolafe AA, Sanusi RA. Does Nutrition Knowledge and Practice of Athletes Translate to Enhanced Athletic Performance? Cross-Sectional Study Amongst Nigerian Undergraduate Athletes. Glob J Health Sci. 2015;7:215-25.

18. Seyhan S. Evaluation of the Use of Nutrition Support Products in Taekwondo Athletes. J Educ Learn. 2018;7:222.

19. Potgieter S. Sport nutrition: A review of the latest guidelines for exercise and sport nutrition from the American College of Sport Nutrition, the International Olympic Committee and the International Society for Sports Nutrition. South African J Clin Nutr. 2013;26:6-16.

20. Phillips SM, van Loon LJC. Dietary protein for athletes: From requirements to optimum adaptation. J Sports Sci. 2011;29.

21. Rodriguez NR, DiMarco NM, Langley S. Position of the American Dietetic Association, Dietitians of Canada, and the American College of Sports Medicine: Nutrition and athletic performance. J Am Diet Assoc. 2009;109:509-27.

22. Ekblom B, Goldbarg AN, Gullbring B. Response to exercise after blood loss and reinfusion. J Appl Physiol [Internet]. 1972 [cited 2020 May 11];33:175-80. Available from: https://journals.physiology.org/doi/abs/10.1152/jappl.1972.33.2.175

23. Government of Nepal, National Planning Comission, Central Bureau of Statistics(CBS). National Population and Housing Census 2011 [Internet]. 2012. Available from: http://old.cbs.gov.np/image/data/Population/National Report/National Report.pdf

24. Koley S, Kaur SP. Correlations of handgrip strength with selected hand-arm-anthropometric variables in Indian inter-university female volleyball players. Asian J Sports Med [Internet]. 2011 [cited 2020 May 2];2:220-6. Available from: https://www.ncbi.nlm.nih.gov/pmc/articles/PMC3289218/

25. Zawila LG, Steib C-SM, Hoogenboom B. The female collegiate cross-country runner: nutritional knowledge and attitudes. J Athl Train. 2003;38:67.

26. Supriya V, Ramaswami L. Knowledge, attitude and dietary practices of track and field athletic men and women aged 18-22 years. Int J Innov Res Dev. 2013;2:399-404.

27. Kamala K, Bhaskaram P, Bhat RV RT. DIETARY GUIDELINES - A Manual [Internet]. Natl. Inst. Nutr. 2011. Available from: http://ninindia.org/DietaryGuidelinesforNINwebsite.pdf

28. National Institute of Nutrition, Hyderabad, India. NSI Diet Calculator [Internet]. [cited 2020 May 4]. Available from: http://www.nutritionsocietyindia.org/downloads.html

29. World Health Organization (WHO). WHO Physical status: The use of and interpretation of anthropometry. Report of a WHO Expert Consultation. Geneva: World Health Organization. [Internet]. 1995. Available from: https://apps.who.int/iris/bitstream/handle/10665/37003/WHO_TRS_854.pdf? sequence $=1$ 
30. Smith JW, Holmes ME, McAllister MJ. Nutritional Considerations for Performance in Young Athletes. J Sports Med [Internet]. Hindawi Publishing Corporation; 2015;2015:1-13. Available from: https://www.ncbi.nlm.nih.gov/pmc/articles/PMC4590906/pdf/JSM2015-734649.pdf

31. Abbey EL, Wright CJ, Kirkpatrick CM. Nutrition practices and knowledge among NCAA Division III football players. J Int Soc Sports Nutr. Journal of the International Society of Sports Nutrition; 2017;14:1-9.

32. Condo D, Lohman R, Kelly M, Carr A. Nutritional intake, sports nutrition knowledge and energy availability in female Australian rules football players. Nutrients. 2019;11:1-13.

33. Hornstrom GR, Friesen CA, Ellery JE, Pike K. Nutrition Knowledge, Practices, Attitudes, and Information Sources of Mid-American Conference College Softball Players. Food Nutr Sci. 2011;02:109-17.

34. Muwonge $\mathrm{H}$, Zavuga R, Kabenge PA, Makubuya T. Nutritional supplement practices of professional Ugandan athletes: A cross-sectional study. J Int Soc Sports Nutr. Journal of the International Society of Sports Nutrition; 2017;14:1-10.

35. Braun H, Koehler K, Geyer H, Kleinert J, Mester J, Schänzer W. Dietary Supplement Use Among Elite Young German Athletes. Int J Sport Nutr Exerc Metab. 2009;19:97-109.

36. Wierniuk A, Włodarek D. Estimation of energy and nutritional intake of young men practicing aerobic sports. Rocz Państwowego Zakładu Hig. 2013;64:143-8.

37. Burke LM, Hawley JA, Wong SHS, Jeukendrup AE. Carbohydrates for training and competition. J Sports Sci. 2011;29.

38. Cook CM, Haub MD. Low-carbohydrate Diets and Performance. Curr Sports Med Rep. Ovid Technologies (Wolters Kluwer Health); 2007;6:225-9.

39. Campbell B, Kreider RB, Ziegenfuss T, La Bounty P, Roberts M, Burke D, et al. International Society of Sports Nutrition position stand: Protein and exercise [Internet]. J. Int. Soc. Sports Nutr. BioMed Central; 2007 [cited 2020 May 2]. p. 8. Available from: http://jissn.biomedcentral.com/articles/10.1186/1550-2783-4-8

40. Thomas DT, Burke LM, Erdman KA. Nutrition and Athletic Performance. Med Sci Sports Exerc. 2016;48:543-68.

41. International Life Sciences, Institute-India, National Institute of Nutrition, Sports Authority of India. Nutrition and Hydration Guidelines for Excellence in Sports Performance [Internet]. 2007. Available from: http://www.ilsi-india.org/PDF/Conf. recommendations/Nutrition/Nutrition \& Hyd. Guidelines for Athletes Final report.pdf

42. Hinton PS. Iron and the endurance athlete. Appl. Physiol. Nutr. Metab. National Research Council of Canada; 2014. p. 1012-8.

43. Kreider RB, Wilborn CD, Taylor L, Campbell B, Almada AL, Collins R, et al. ISSN exercise and sport nutrition review: Research and recommendations. J Int Soc Sports Nutr. 2010;7:1-43.

\section{Tables}


Table 1 Socio-demographic and anthropometric characteristics with DHGS score of the study participants $(n=293)$ 


\begin{tabular}{|c|c|c|c|c|}
\hline Variables & Characteristics & $\begin{array}{l}\text { Frequency } \\
(\%)\end{array}$ & $\underset{\text { SD }}{\operatorname{Mean} \pm}$ & $\begin{array}{c}\text { P- } \\
\text { value }^{1,} \\
2\end{array}$ \\
\hline Sex & $\begin{array}{l}\text { Male } \\
\text { Female }\end{array}$ & $\begin{array}{l}185(63.1) \\
108(36.8)\end{array}$ & $\begin{array}{l}38.3 \pm \\
17.3 \\
24.1 \pm \\
11.1\end{array}$ & $<0.001^{*}$ \\
\hline Religion & $\begin{array}{l}\text { Hindu } \\
\text { Non Hindu }\end{array}$ & $\begin{array}{l}208 \text { (70.9) } \\
85 \text { (29) }\end{array}$ & $\begin{array}{c}34.4 \pm \\
17.6 \\
30 \pm 14.1\end{array}$ & $0.020^{*}$ \\
\hline Ethnicity & $\begin{array}{l}\text { Advantage ethnic } \\
\text { groups } \\
\text { Disadvantage ethnic } \\
\text { group }\end{array}$ & $\begin{array}{l}131(44.7) \\
162(55.3)\end{array}$ & $\begin{array}{l}33.1 \pm \\
17.2 \\
33.2 \pm \\
30.6\end{array}$ & 0.532 \\
\hline Education level & $\begin{array}{l}\text { Secondary or lower } \\
\text { Higher secondary or } \\
\text { above }\end{array}$ & $\begin{array}{l}132(45.1) \\
161(54.9)\end{array}$ & $\begin{array}{l}27.9 \pm \\
16.4 \\
37.4 \pm \\
15.8\end{array}$ & $<0.001^{*}$ \\
\hline Occupation & $\begin{array}{l}\text { Students } \\
\text { Service }\end{array}$ & $\begin{array}{l}221(75.4) \\
72(24.5)\end{array}$ & $\begin{array}{l}29.5 \pm \\
14.8 \\
44.1 \pm \\
17.5\end{array}$ & $<0.001^{*}$ \\
\hline $\begin{array}{l}\text { Monthly family income (NRs) } \\
\text { (1USD=110NRs) }\end{array}$ & $\begin{array}{l}<50,000 \\
\geq 50,000\end{array}$ & $\begin{array}{l}205(69.9) \\
88(30)\end{array}$ & $\begin{array}{l}32.4 \pm \\
16.4 \\
34.6 \pm \\
17.5\end{array}$ & 0.310 \\
\hline Training hour per day & $\begin{array}{l}<4 \text { hours } \\
\geq 4 \text { hours }\end{array}$ & $\begin{array}{l}214(73) \\
79(26.9)\end{array}$ & $\begin{array}{l}29.6 \pm \\
14.6 \\
42.6 \pm \\
18.5\end{array}$ & $<0.001^{*}$ \\
\hline Smoking habit & $\begin{array}{l}\text { Yes } \\
\text { No }\end{array}$ & $\begin{array}{c}7(2.4) \\
286(97.6)\end{array}$ & $\begin{array}{l}42.4 \pm \\
18.2 \\
32.9 \pm \\
16.7\end{array}$ & 0.138 \\
\hline Consumption of alcohol & $\begin{array}{l}\text { Yes } \\
\text { No }\end{array}$ & $\begin{array}{c}7(2.4) \\
286(97.6)\end{array}$ & $\begin{array}{l}48.2 \pm \\
15.4 \\
32.7 \pm \\
16.6\end{array}$ & $0.015^{*}$ \\
\hline Family type & $\begin{array}{l}\text { Nuclear } \\
\text { Joint }\end{array}$ & $\begin{array}{l}165(56.3) \\
128(43.6)\end{array}$ & $\begin{array}{c}32.5 \pm \\
16.9 \\
33.8 \pm \\
16.6\end{array}$ & 0.501 \\
\hline BMI $\left(\mathrm{kg} / \mathrm{m}^{\wedge} 2\right)$ & $\begin{array}{l}\text { Underweight } \\
\text { Normal } \\
\text { Overweight }\end{array}$ & $\begin{array}{l}56(19.1) \\
231(78.8) \\
6(2.1)\end{array}$ & $\begin{array}{c}24.4 \pm 11 \\
35 \pm 17.2 \\
42.6 \pm \\
18.7\end{array}$ & $<0.001^{*}$ \\
\hline Nutrition knowledge score & $\begin{array}{l}\text { Poor } \\
\text { Good }\end{array}$ & $\begin{array}{c}165 \\
(56.31) \\
128 \\
(43.69)\end{array}$ & $\begin{array}{c}31.78 \pm \\
16.19 \\
34.89 \pm \\
17.40\end{array}$ & 0.116 \\
\hline Nutrition practice score & Poor & 163 & $33.26 \pm$ & 0.889 \\
\hline
\end{tabular}




\begin{tabular}{|c|c|c|c|c|}
\hline & Good & $\begin{array}{c}(55.63) \\
130 \\
(44.37)\end{array}$ & $\begin{array}{c}16.74 \\
32.99 \pm \\
16.88\end{array}$ & \\
\hline Sports supplements use & $\begin{array}{l}\text { Yes } \\
\text { No }\end{array}$ & $\begin{aligned} & 21(7.2) \\
& 272(92.8)\end{aligned}$ & $\begin{array}{c}30.9 \pm \\
16.6\end{array}$ & 0.530 \\
\hline Total nutrition knowledge score & - & - & $9.0+2.0$ & - \\
\hline Total nutrition practice score & - & - & $\begin{array}{c}10.24+ \\
1.8\end{array}$ & - \\
\hline Age (years) & - & - & $\begin{array}{c}18.8 \pm \\
4.5\end{array}$ & - \\
\hline Height (feet) & - & - & $5.2 \pm 0.4$ & - \\
\hline Weight (kg) & - & - & $52 \pm 11.1$ & - \\
\hline BMI $\left(\mathrm{kg} / \mathrm{m}^{\wedge} 2\right)$ & - & - & $\begin{array}{c}20.3 \pm \\
2.5\end{array}$ & - \\
\hline $\begin{array}{l}\text { Right handgrip } \\
\text { strength score }\end{array}$ & - & - & $\begin{array}{c}35.4 \pm \\
16.9\end{array}$ & - \\
\hline Left handgrip strength score & - & - & $\begin{array}{c}30.8 \pm \\
17.6 \\
\end{array}$ & - \\
\hline
\end{tabular}

Table 2 Nutritional knowledge and nutrition practice among Taekwondo players $(n=293)$

\begin{tabular}{|c|c|c|c|c|c|}
\hline Variables & & Nutritional & ctice score & & \\
\hline Nutritional knowledge score & & Poor & Good & $\bar{\chi}$ test & P-value \\
\hline & & n (\%) & n (\%) & & \\
\hline & Poor & $107(64.8)$ & $58(35.2)$ & 12.9 & $<0.001^{*}$ \\
\hline & Good & $56(43.7)$ & $72(56.3)$ & & \\
\hline & Total & 163 (55.6) & $130(44.4)$ & & \\
\hline
\end{tabular}

* denotes statistically significant at $\mathrm{P}<0.05$

Table 3 Description of daily nutrient intake per day compared to corresponding RDA of Taekwondo players $(n=293)$ 


\begin{tabular}{lcccc}
\hline Nutrient intake & Median (25,75) & RDA $^{1}$ & $\begin{array}{c}\text { Percent meeting lower than } \\
\text { RDA }^{2}\end{array}$ & $\begin{array}{c}\text { P } \\
\text { value }^{3}\end{array}$ \\
\hline $\begin{array}{l}\text { Total energy } \\
\text { (kcal) }\end{array}$ & $\begin{array}{c}2367.8(2035, \\
2716.8)\end{array}$ & 3600 & $77 \%$ & $<0.001^{*}$ \\
$\begin{array}{l}\text { Carbohydrate } \\
(\mathrm{gm})\end{array}$ & $430.5(340.9,503.8)$ & 494 & $87.1 \%$ & $<0.001^{*}$ \\
\hline Protein (gm) & $79.5(66.8,95.1)$ & 135 & $58.8 \%$ & $<0.001^{*}$ \\
\hline Fat (gm) & $71.2(55.5,89.2)$ & 124 & $57.4 \%$ & $<0.001^{*}$ \\
\hline Calcium (mg) & $416(178,448)$ & 800 & $47 \%$ & $<0.001^{*}$ \\
\hline Iron (mg) & $7(3.8,12)$ & 28 & $32 \%$ & $<0.001^{*}$ \\
\hline
\end{tabular}

Median $(25,75)$ : median and interquartile range

$\mathrm{RDA}^{1}$ :Recommended Dietary Allowance for Weight division category Group-IV of athletes [41]

${ }^{2}$ Percent of individuals with intakes lower than the adequate intake (AI) level

3 wilcoxon sign-ranked test

*denotes statistically significant at $\mathrm{p}<0.05$

Table 4 Correlation of anthropometric measurements, nutrition knowledge, practice and nutrient intake with athletic performance among Taekwondo players $(n=293)$

\begin{tabular}{lcc}
\hline Variables & \multicolumn{2}{c}{ DHG score } \\
\cline { 2 - 3 } & Pearson correlation (r) & P-value \\
\hline Height (feet) & 0.538 & $0.001^{*}$ \\
Weight $(\mathrm{kg})$ & 0.651 & $0.001^{*}$ \\
\hline BMI $\left(\mathrm{kg} / \mathrm{m}^{2}\right)$ & 0.347 & $0.001^{*}$ \\
\hline NK score & 0.117 & $0.045^{*}$ \\
\hline NP score & 0.008 & 0.957 \\
\hline Supplements use & 0.050 & 0.387 \\
\hline CHO Intake (g) & 0.085 & 0.145 \\
\hline Protein Intake(g) & 0.128 & 0.608 \\
\hline Fat Intake (g) & 0.075 & $0.002^{*}$ \\
\hline Calcium Intake (mg) & 0.054 & 0.355 \\
\hline Iron Intake (mg) & -0.004 & 0.994 \\
\hline Energy (kcal) & 0.127 & $0.029^{*}$ \\
\hline
\end{tabular}

*denotes statistically significant at p<0.05; DHG score: Dominant handgrip score, NK: Nutrition knowledge, NP: Nutrition practice 
Table 5 linear regression analysis of anthropometric measurement, nutrition knowledge, practice, and nutrient intake with athletic performance among Taekwondo players $(n=293)$

\begin{tabular}{|c|c|c|c|}
\hline Variables & $\beta(95 \% \mathrm{CI})$ & $\mathrm{SE}$ & P-value \\
\hline Training hour per day & $0.41(-0.09-0.91)$ & 0.61 & $<0.001^{*}$ \\
\hline $\operatorname{BMI}\left(\mathrm{kg} / \mathrm{m}^{\wedge} 2\right)$ & $0.35(0.09-0.61)$ & 0.37 & $<0.001^{*}$ \\
\hline Nutrition knowledge score & $0.13(0.01-0.25)$ & 0.47 & $0.024^{*}$ \\
\hline Nutrition practice score & $-0.03(0.001-0.061)$ & 0.53 & 0.543 \\
\hline Nutrient intake & & & \\
\hline Energy (kcal) & $0.13(0.12-0.14)$ & 0.001 & $0.035^{*}$ \\
\hline Carbohydrate (gm) & $0.05(0.04-0.052)$ & 0.002 & 0.343 \\
\hline Protein $(\mathrm{gm})$ & $0.13(0.12-0.14)$ & 0.01 & 0.124 \\
\hline Fat $(\mathrm{gm})$ & $0.11(0.10-0.12)$ & 0.007 & 0.054 \\
\hline Calcium (mg) & $0.05(0.04-0.06)$ & 0.004 & 0.425 \\
\hline Iron $(\mathrm{mg})$ & $0.02(0.01-0.03)$ & 0.13 & 0.667 \\
\hline
\end{tabular}

\section{Figures}

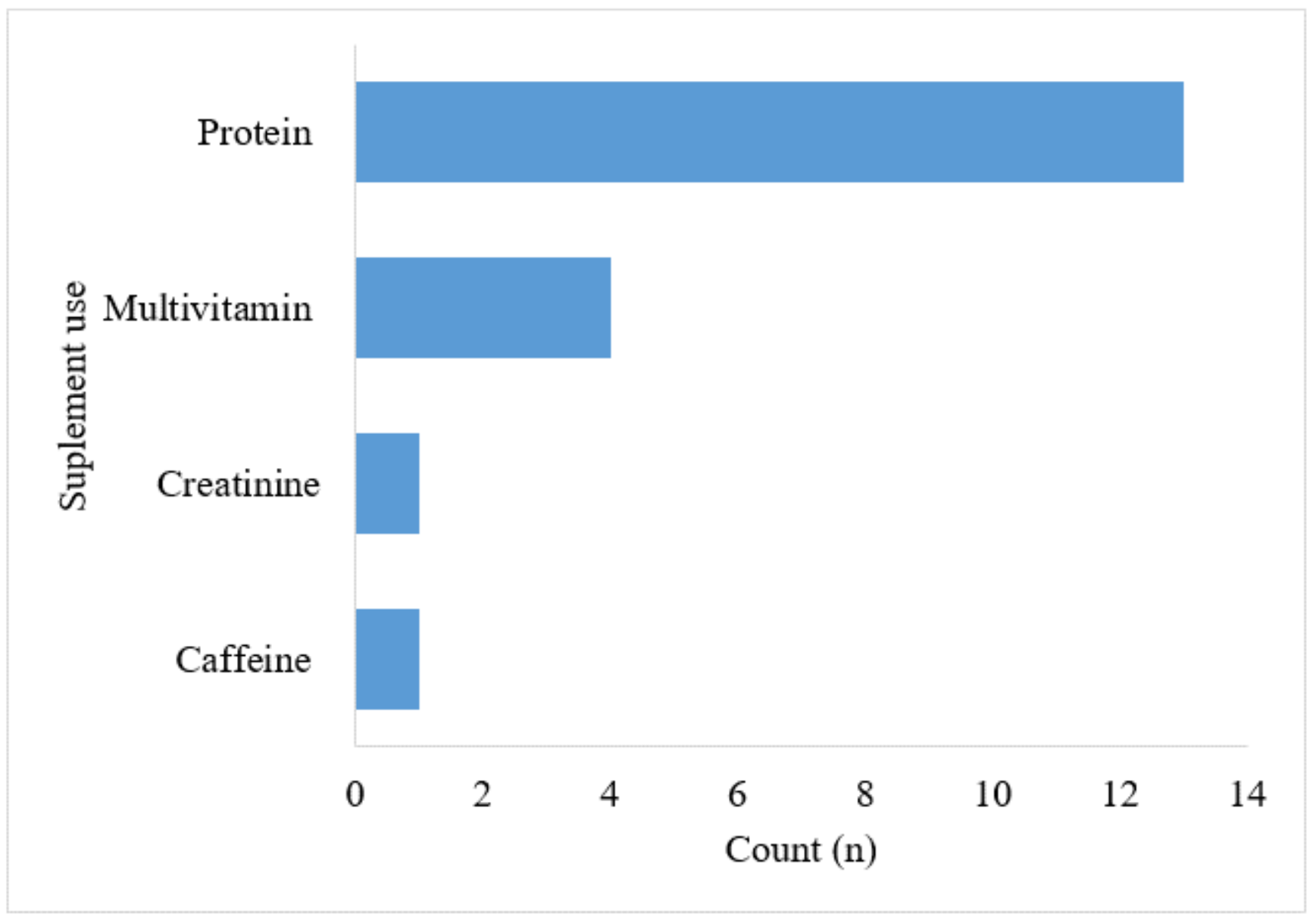


Figure 1

Type of supplement used by Taekwondo players $(n=21)$ 